Limnol. Rev. (2015) 15, 3: 107-118

\title{
Meteorological conditions, physiochemical properties, thermal-oxygen stratification, water overturn and water balance of Lake Gardno on Wolin Island
}

\author{
Jacek Tylkowski, Mariusz Samołyk \\ Institute of Geoecology and Geoinformation, Adam Mickiewicz University in Poznań, Dzięgielowa 27, 61-680 Poznań, Poland, e-mail: \\ jatyl@amu.edu.pl (corresponding author),mars@amu.edu.pl
}

\begin{abstract}
The main research problem of the paper is aimed at determining the proper functioning of Lake Gardno within the period 2012-2014 considered as hydrological years in reference to the physiochemical properties of its waters, water balance, thermal regime and water overturn. Lake Gardno is a representative of non-run-off lake geo-eco-systems; it is situated within the Southern Baltic Sea Coastland at the cliff shore of Wolin Island. The paper analyses how weather conditions affect the specifics of water supplies provided to the lake and seasonal dynamics of its waters, their chemical, thermal and aerobic properties. It also specifies their overturn and balance with a particular emphasis on their supplies together with fog deposits.
\end{abstract}

Key words: Lake Gardno, Wolin Island, thermal and oxygen stratification, water overturn, hydrochemistry, water balance

\section{Introduction}

Today's functioning of lake geo-systems is considered in temporal and spatial terms (Kostrzewski 2003). To specify geo-ecological conditions of lakes within the Baltic Sea Coastland, it is essential to illustrate some regularities of temporal variability of physical-chemical properties of their waters, turnover and balance.

As for lake geo-eco-systems at Wolin Island, no detailed studies are available on the impacts of meteorological conditions on them. It refers, in particular, to the role of fog deposits in the formation of seasonal diversification of their water balance and physiochemical properties. Moreover, it is relevant to demonstrate impacts of weather conditions on their water turnover and thermal-aerobic stratification.

The coastal catchment of Lake Gardno constitutes a primary unit of research studies at Wolin Island in the scope of transformation of water physiochemical properties, both in atmospheric (precipitation in an open field, throughfall, stemflow) and lithospheric (soil waters, underground waters, surface lakes) stage of water circulation. A model of water circulation was formulated for this coastal, non-run-off and forested geo-eco-system within Lake Gardno. It was based on concentration and loads of solutes at particular stages of water circulation, which allows their water and ionic balance to be formulated (Kolander et al. 2008; Kolander and Tylkowski 2008; Kostrzewski et al.2011). The characteristics of temporal and spatial variability of hydro-chemical properties of lakes within Wolin Island was the subject of research studies conducted, among others, by Choiński et al. (1978), Kubiak (2001, 2003), Poleszczuk et al. (2006). Water resources and their balance within Wolin Island were the subject of papers developed, among others, by Nowacki (1994), Samołyk and Tylkowski (2012).

The primary goal of the paper is to determine the meteorological conditions of temporal variability of water overturn and balance of Lake Gardno and physiochemical properties of its waters: temperature, oxygenation, electrolytic conductivity, water $\mathrm{pH}$ and concentration of solutes. The achieved regularities reflect the specifics of functioning of non-run-off lake geo-eco-systems located in the close proximity of the Southern Baltic Sea Coastline within moraine high lands. The landscape individuality of Lake Gardno is 
determined by its coastal location (250 m from cliff coasts of the Zatoka Pomorska [Pomeranian Bay]), surface non-run-off, extensive morphological diversification and full forestation of its catchment as well as significant participation of fogs in the supply of water and sea aerosols. As for Lake Gardno, there was also its natural susceptibility to degradation, the threat of eutrophication and permanence of its basin.

Lake Gardno with its catchment area of 265 ha is located within a cumulated frontal moraine and represents coastal early-glacial landscapes. Its land height variances nearly reach $100 \mathrm{~m}$. The area under consideration is fully forested (mainly beech and mixed forests, with added pine, oak and - less frequently - spruce trees). The catchment area is dominated by podzolic, podzolic-rustic and brown sour soils, developed mainly on fine-grained sands (Kolander et al. 2008). Lake Gardno with its area of 2.5 ha and location in the north-eastern part of the catchment at $16.5 \mathrm{~m}$ above sea level is the only hydrographical unit within the catchment area.

Lake Gardno has ambiguous origins. According to Choiński et al. (1986) Lake Gardno is a bottommoraine lake which is a rather doubtful thesis as the lake under consideration fills a concave form of land within the most hypsometrically diverse physical- geographical unit of Wolin Island, which constitutes a frontal moraine (Fig. 1). Taking into consideration the location of this lake, it is of a moraine-lake type in its origin; in the 15th century it was subjected to anthropogenic changes - as a result of opencast mining activities in search of gold ores run in 1560 (Pluciński 2009). The shape of its bottom in the northern bay may provide evidence on the anthropogenic transformation of its basin. This lake bottom takes the form of a pit (ditch) with its depth down to $7 \mathrm{~m}$ and considerably steep slopes up to $80^{\circ}$. Depths of other lake areas which presumably were not subjected to such anthropogenic transformations do not exceed $4 \mathrm{~m}$ and their lake slopes are much smoother. In addition, a high level of concentration of zinc at $1081 \mathrm{mg} \mathrm{kg}^{-1}$ of dry matter was found within bottom deposits collected at the deepest point of the lake $(7 \mathrm{~m})$ at a depth of $20-25 \mathrm{~cm}$. This high level may indicate anthropogenic contamination of deposits (Walczak 2013). Estimating the sedimentation of bottom deposits in the profundal zone of moraine lakes within the early glacial area of the Polish Lowland $0.5 \mathrm{~mm} \mathrm{yr}^{-1}$ (Rutkowski et al. 2002), the 'age' of this contamination of Lake Gardno sediments with zinc can be related to mining works taking place in the 16th century. Therefore, Lake Gardno is probably a polygenetic lake.

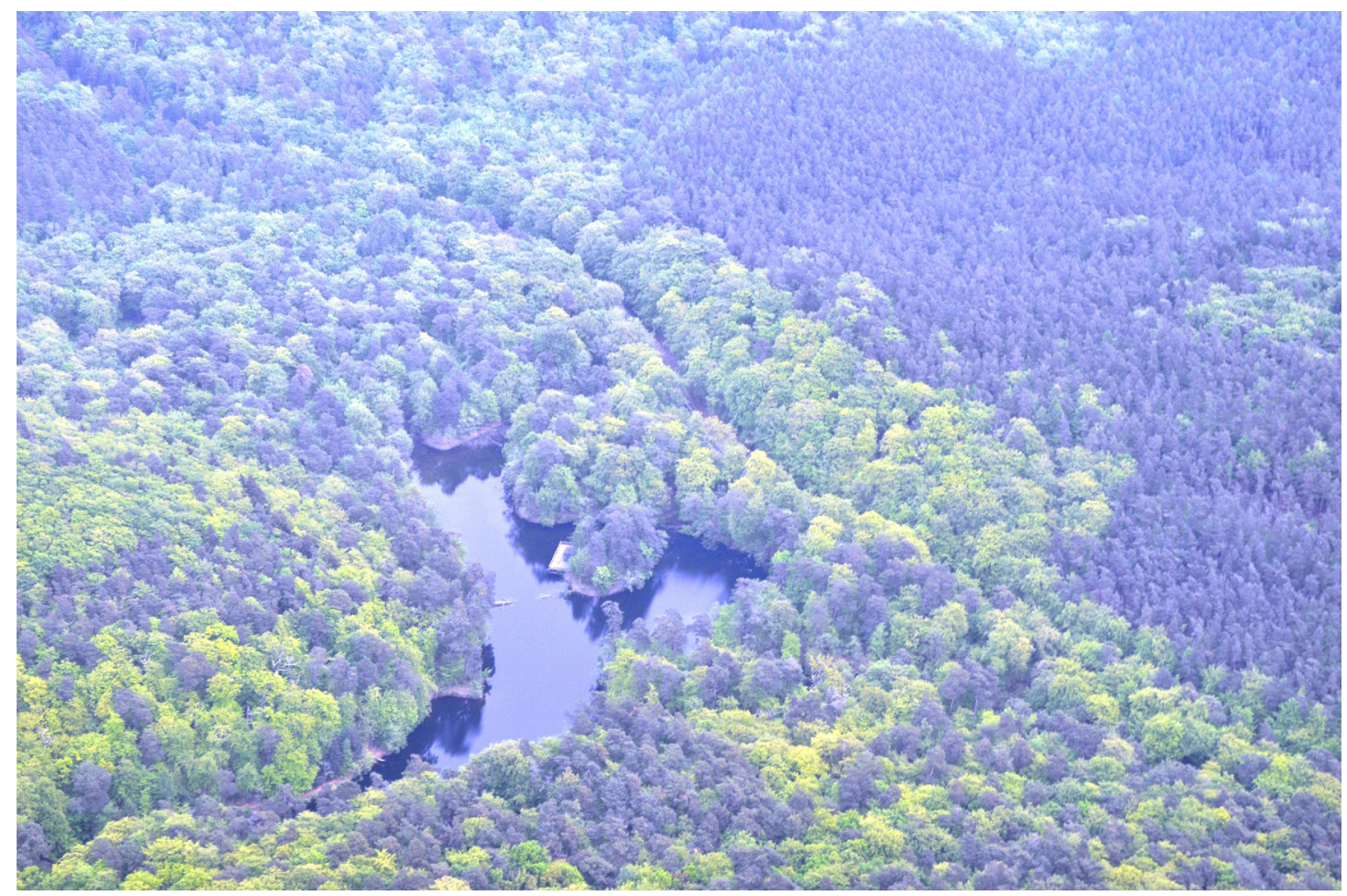

Fig. 1. Lake Gardno at Wolin Island 


\section{Methods}

The research studies on physiochemical properties of lake waters and hydro-meteorological conditions of Lake Gardno geo-eco-system were run with the use of the measuring system at the Natural Environment Monitoring Station of Adam Mickiewicz University in Biała Góra. At the meteorological station in Biała Góra weather components were measured with the application of Vaisala Milos 520 automatic unit. The author of the paper makes use of daily data on meteorological conditions determining the lake habitat: average air temperatures, total precipitation, evaporation from free water surfaces, wind, its predominant directions, average and maximal speeds. Within the period 2012-2014 taken as hydrological years at 2-hour intervals measurements were run within Lake Gardno at one of its deepest points $(6.9 \mathrm{~m})$ with the use of Hobo temperature recorders. They covered its thermal regime at depths: 0.3 , $1,2,3,4,5$ and $6 \mathrm{~m}$ and within non-consolidated bottom deposits - at a depth of $7 \mathrm{~m}$. At quarterly intervals, during spring/autumn circulations and summer/winter stagnations, measurements were run - at the deepest depth profile - on oxygenation, electrolytic conductivity, water $\mathrm{pH}$ with the use of a Hanna HI 9828 multifunctional meter. Moreover, the lake water level and its water supplies together with fog deposits were monitored on a continuous basis. In July 2012 bathymetric measurements were run - at the lake average water level - with the use of a Lowrance HDS 5 echo-sounder with GPS positioning at $10-\mathrm{cm}$ accuracy.

To determine Lake Gardno water balance, the following formula was applied: $\mathrm{P}+\mathrm{F}-\mathrm{E}+\Delta \mathrm{Z}=\Delta \mathrm{R}$ (where: $\mathrm{P}$ - precipitation, $\mathrm{F}$ - fog, $\mathrm{E}$ - water evaporation, $\Delta \mathrm{Z}$ resultant underground supplies, $\Delta \mathrm{R}$ - variance of the lake retention between the start and end of its balance period). The above shortened equation of the lake water balance is a modification of the formula developed by Mikulski (1970) and Bajkiewicz-Grabowska (1982, 2009) by adding fog deposits to water in-take components and eliminating horizontal surface exchanges. As for Lake Gardno, due to a lack of surface water inflows and outflows from the lake, water vertical and underground exchanges have the largest impact on the balance equation and its formulation.

Natural susceptibility and resistance of Lake Gardno against degradation was determined on the grounds of the methodology developed by BajkiewiczGrabowska (1987) while permanence of its basin was based on the method suggested by Kerekes (1977).

\section{Results and discussion}

\section{Bathymetry and shape of the coastline}

Lake Gardno is a shallow lake; its maximal depth is equal to $7.3 \mathrm{~m}$ and average depth, $2.5 \mathrm{~m}$. The coastline is very well developed; its length is $1640 \mathrm{~m}$ with a high 'coastline development' index at 2.82. The lake length is $474 \mathrm{~m}$ and maximal width, $120 \mathrm{~m}$. The lake waters' volume is equal to $61.600 \mathrm{~m}^{3}$. Lake Gardno is the only lake on Wolin Island which has its own island (with an area of 14 acres). Its 'island-saturation' index is at $5.6 \%$. The bathymetric measurements run in July 2012 confirmed a substantial level of depth diversification within the lake area (its water regions) (Fig. 2). The depth diversification of Lake Gardno water regions is very high. In bathymetric terms, a bay in the northern part of the lake with its maximal depth equal to $7.3 \mathrm{~m}$ stands out considerably. The configuration of its bottom, historical records and contamination of bottom deposits suggest that mining works were conducted within this part of the reservoir. Due to bathymetric considerations thermal stratification occurs only in the northern part of the lake. There is no thermal stratification in other, much shallower, water regions; water mixing due to wind surging occurs very often here.

Lake Gardno - taking depth conditions of other lakes on Wolin Island - is a relatively deep and smallarea reservoir. It has quite favourable parameters of its basin (its shape) which are conducive to water retention. Its depth index is equal to 0.38 ; volumetric development index - 1.13; exposure index - 1.0; and basin compactness index -2.6 . The lake coastline covered with trees also favours water retention as it reduces water evaporation as a consequence of reduced wind speeds.

\section{Weather conditions}

For Lake Gardno catchment the analysed hydrological years (2012-2014) were characterised by rather unfavourable thermal and precipitation conditions which did not lead to any improvement of water resources. In terms of thermal and precipitation classification these years were relatively warm, with a high level of evaporation from free water surfaces, average precipitation, snow cover and anemometric conditions. These meteorological conditions affecting the circulation of water are characterised by a high level of their diversity (Table 1). In 2012 high total evaporation from free water surfaces $(592.4 \mathrm{~mm})$ and 


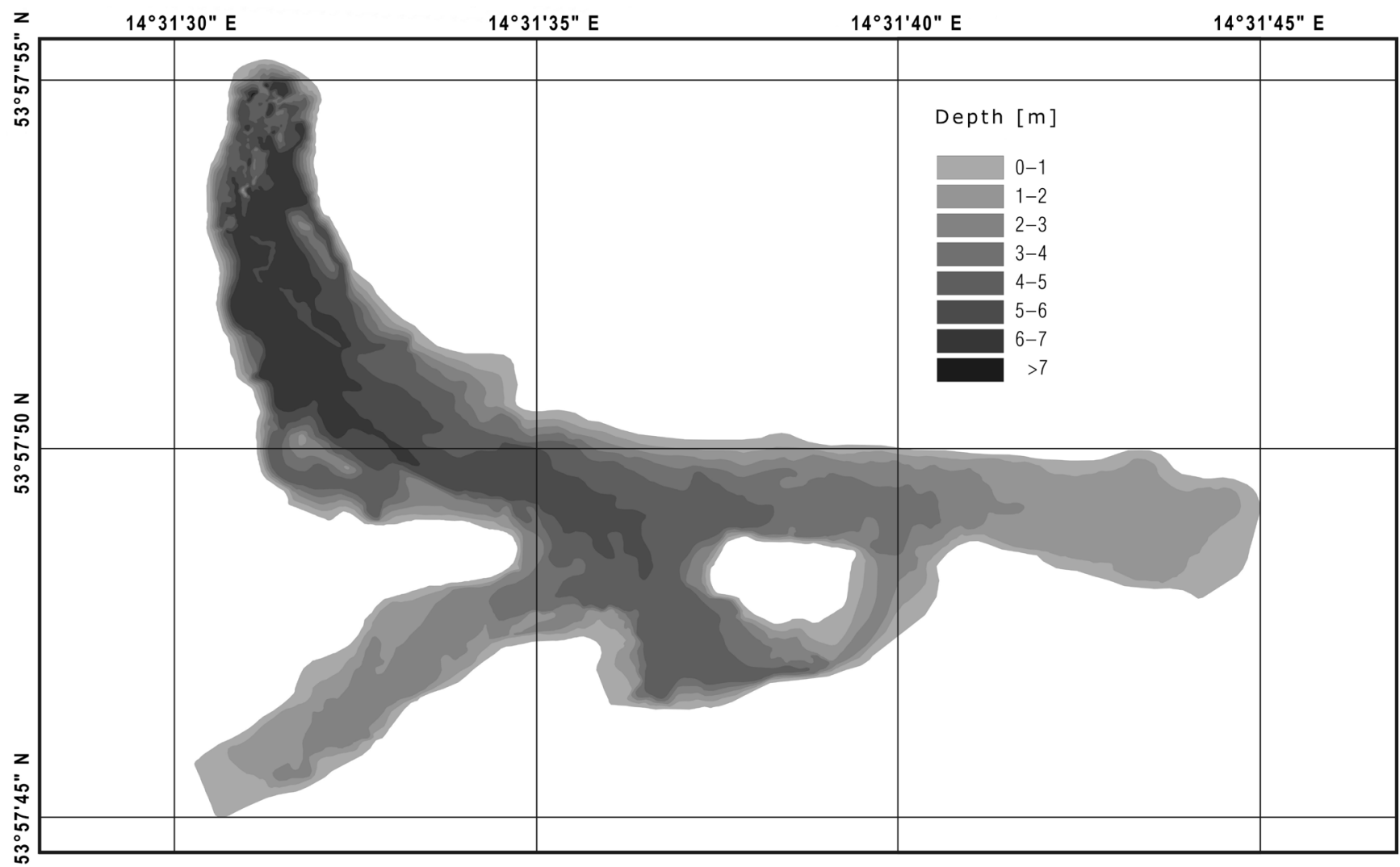

Fig. 2. Bathymetry of Lake Gardno

considerable supplies of water with fog deposits (111.2 $\mathrm{mm}$ ) were reported (Tylkowski 2013). The annual average wind speed was quite low at $1.5 \mathrm{~m} \mathrm{~s}^{-1}$. The level of snow supply and its impact was negligible as snow lay for 17 days with its average thickness reaching 5 $\mathrm{cm}$ only. In 2013 the highest level of water supplies together with precipitation was reported $(629.5 \mathrm{~mm})$. By contrast, annual evaporation within the examined three-year-period was the lowest $(533.6 \mathrm{~mm}) .2013$ was exceptional in terms of snow cover which lay for 3 months with an average thickness of $9 \mathrm{~cm}$. The last research year (2014) was exceptional in thermal terms with its extremely high average annual air tempera- ture at $10.4^{\circ} \mathrm{C}$. The level of water supplies with fog deposits was the lowest $(72.3 \mathrm{~mm})$ and snow coverage negligible (for less than 2 weeks).

On the grounds of the annual characteristics of meteorological conditions it cannot be stated that there are any directly proportional dependencies between and among weather components having an impact on water resources and level of Lake Gardno catchment. For example in 2014 - in spite of very high average air temperatures and the highest wind speeds - there was no highest total evaporation derived from free water surfaces. Then in 2012 - in spite of low wind speeds and relatively average thermal conditions - the level of

Table 1. Meteorological conditions of Lake Gardno catchment during the analysed hydrological years (2012-2014)

\begin{tabular}{|c|c|c|c|c|c|c|c|}
\hline \multirow{3}{*}{ Year } & \multirow{2}{*}{$\begin{array}{l}\text { Average air } \\
\text { temperature }\end{array}$} & \multirow{2}{*}{ Precipitation } & \multirow{2}{*}{ Fog } & \multirow{2}{*}{$\begin{array}{l}\text { Evaporation } \\
\text { from water } \\
\text { surface }\end{array}$} & \multicolumn{2}{|c|}{ Average snow cover } & \multirow{2}{*}{ Average wind speed } \\
\hline & & & & & thickness & duration & \\
\hline & {$\left[{ }^{\circ} \mathrm{C}\right]$} & {$[\mathrm{mm}]$} & {$[\mathrm{mm}]$} & {$[\mathrm{mm}]$} & {$[\mathrm{cm}]$} & [days] & {$\left[\mathrm{m} \mathrm{s}^{-1}\right]$} \\
\hline 2012 & 9.3 & 575.5 & 111.2 & 592.4 & 5 & 17 & 1.5 \\
\hline 2013 & 8.8 & 629.5 & 87.3 & 533.6 & 9 & 91 & 2.6 \\
\hline 2014 & 10.4 & 592.4 & 72.3 & 555.8 & 5 & 13 & 3.0 \\
\hline 2012-2014 & 9.5 & 599.1 & 90.3 & 560.6 & 6 & 40 & 2.4 \\
\hline
\end{tabular}


evaporation was very high. Then it can be assumed that the hydrological and physiochemical properties of Lake Gardno are not so much affected by annual meteorological conditions but, above all, by seasonal (especially short-term) variability of weather components.

Variations of water levels and exchanges in the lake

Lake Gardno is characterised by its stable ground-precipitation derived supplies which are reflected in low fluctuations of water levels manifested by the maximal amplitude of their values (fairly $9 \mathrm{~cm}$ ). The average lake level during 2012-2014 was equal to $39 \mathrm{~cm}$ and the range of its variability ranged from 36 $\mathrm{cm}$ up to $45 \mathrm{~cm}$. The lowest water levels in the lake were reported in summer seasons (from June to $\mathrm{Au}$ gust) when their reduced levels were much affected by high air temperatures and increased evaporation. The highest water levels were found in winter-spring periods (from December to April) when water evaporation was limited (Fig. 3). As for Lake Gardno weak dependencies between changes in its water levels and weather conditions were reported. Meteorological conditions have a relatively small effect on fluctuations of water levels in the lake, which provides evidence on stable and quite balanced annual water supplies provided to the lake through underground waters. Even the most abundant precipitation which occurs mainly in summers does not lead to any rapid increases in water levels of the lake, as this atmospheric supply of water is reduced, among others, through raised evaporation within the lake area, e.g. two-hour precipitation with its extreme total of $74 \mathrm{~mm}$ which took place on $3 \mathrm{rd}$ August 2014 led to an increase in water levels in the lake by $1 \mathrm{~cm}$ only. Moreover, due to the full forestation of the lake catchment there is no chance of any increased water supplies provided to the lake together with its surface runoff.

The statistical characteristics of these hydrometeorological conditions showed very low variability of water levels within the lake in relation to weather conditions (Table 2). The variability coefficient of water levels in the lake is very low (5\%). Then by contrast weather elements affecting water levels in the lake have very high daily variability ranging from $71 \%$ for

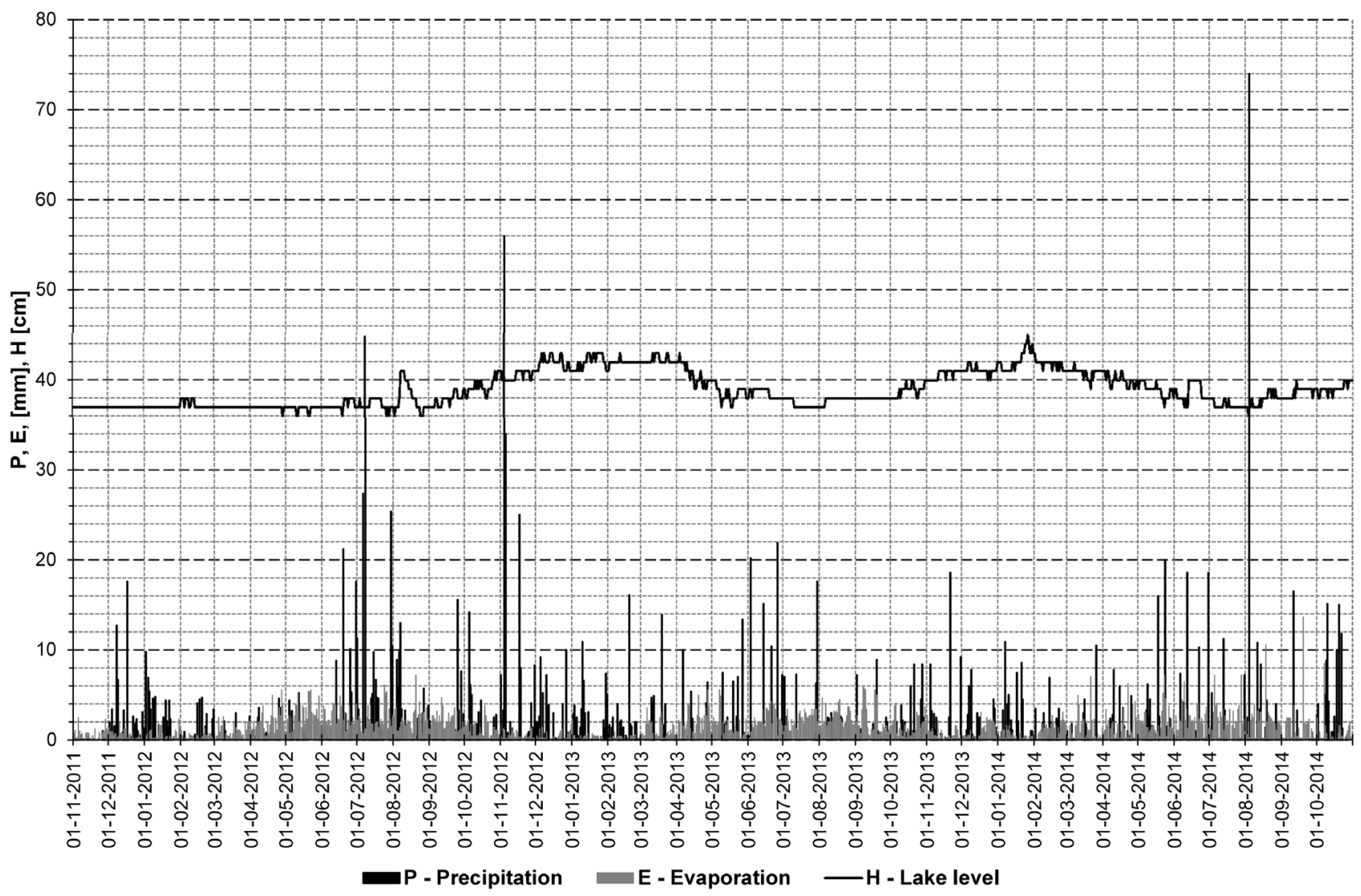

Fig. 3. Dynamics of precipitation, evaporation from free water surfaces and water level in Lake Gardno during 2012-2014 
the average daily wind speed up to $170 \%$ for the daily total precipitation. As for Lake Gardno a statistically significant dependency $(\mathrm{p}<0.05)$ was found between the average daily water level in the lake, daily total evaporation from free water surfaces $(r=-0.31)$ and average daily wind speed $(r=0.40)$. However, no statistically significant dependency $(p<0.05)$ was found between water levels in the lake and the daily total precipitation, which may provide evidence on the low impact of direct water supplies provided to the lake through the atmosphere.

Due to a lack of surface inflows and outflows in Lake Gardno, its horizontal surface exchange is of no significance. Then a stable and relatively balanced level of its underground exchange can be found, which is manifested through small fluctuations of water levels in the lake and similar chemical properties of lake waters (compared to underground waters) within the first aquifer at $13.2 \mathrm{~m}$ above sea level. In Lake Gardno the average value of specific electrolytic conductivity (SEC) being a measure of water mineralization was equal to $46 \mathrm{mS} \mathrm{m}^{-1}$ during 2012-2014. Electrolytic conductivity in the lake was more akin to underground waters $\left(56 \mathrm{mS} \mathrm{m}^{-1}\right)$ rather than to precipitation waters $\left(11 \mathrm{mS} \mathrm{m} \mathrm{m}^{-1}\right)$, which indicates the dominance of underground supplies. Lake Gardno constitutes a drainage area of quaternary waters, especially from within Holocene layers with their free surfaces and usually not covered with impermeable forms, which facilitates infiltration of precipitation waters. The $1^{\text {st }}$ aqui- fer layers water tables are positioned with their shape conforming to the terrain and waters of these layers through hydro-geological gaps feed Pleistocene interclay layers with tense surfaces (Matkowska 1973), which locally can also supply the lake basin.

While analysing the lake basin supplies it was found that there is a clear link between variability of water levels in the lake and underground water levels, especially within the $1^{\text {st }}$ aquifer $(r=-0.80 ; \mathrm{p}<0.05)$ when compared to precipitation supplies $(\mathrm{r}=0.12$; $\mathrm{p}>$ 0.05 ). The very strong, statistically significant, negative correlation between the $1^{\text {st }}$ aquifer and the lake level may attest to the drainage of underground waters in the northern deepest region of the lake.

\section{Water balance of Lake Gardno}

The shortened water balance for the period of 2012-2014 was calculated referring to its vertical water exchange (Table 3). Its hydro-meteorological components were calculated on the grounds of our own measurements of atmospheric precipitation, fogs, evaporation from free water surfaces and water volume in the lake being a measure of lake retention. Together with atmospheric precipitation, waters at an amount of $14.978 \mathrm{~m}^{3}$ reach the lake, which constitutes $87 \%$ of its vertical water supplies. The remaining $13 \%$ is made by vertical water supplies in the form of fogs (at an amount of $2258 \mathrm{~m}^{3}$ per year). When looking from the perspective of water losses, waters at an amount of $14.015 \mathrm{~m}^{3}$ on average evaporate from the

Table 2. Statistical characteristics of daily meteorological conditions and Lake Gardno level during 2012-2014

\begin{tabular}{|c|c|c|c|c|c|}
\hline \multirow{2}{*}{ Statistical parameter } & Lake level & Precipitation & Evaporation & Wind speed & Temperature \\
\hline & {$[\mathrm{cm}]$} & {$[\mathrm{mm}]$} & {$[\mathrm{mm}]$} & {$\left[\mathrm{m} \mathrm{s}^{-1}\right]$} & {$\left[{ }^{\circ} \mathrm{C}\right]$} \\
\hline Average & 39 & 3.7 & 1.5 & 2.4 & 9.5 \\
\hline Median & 38 & 1.8 & 1.3 & 2.2 & 9.7 \\
\hline Mode & 37 & 0.1 & 0.2 & 0.0 & 13.7 \\
\hline Minimum & 36 & 0.1 & 0.0 & 0.0 & -13.3 \\
\hline Maximum & 45 & 74.0 & 13.7 & 13.6 & 25.3 \\
\hline Q1 Lower Quartile & 37 & 0.5 & 0.5 & 1.3 & 4.2 \\
\hline Q3 Upper Quartile & 41 & 4.4 & 2.2 & 3.3 & 15.6 \\
\hline Percentyl 10 & 37 & 0.1 & 0.2 & 0.1 & 0.0 \\
\hline Percentyl 90 & 42 & 9.1 & 3.4 & 4.4 & 18.9 \\
\hline Dispersion & 9 & 73.9 & 13.7 & 13.6 & 38.6 \\
\hline Standard deviation & 1.9 & 6.4 & 1.4 & 1.7 & 7.5 \\
\hline Variability coefficient & 5 & 170 & 91 & 71 & 79 \\
\hline Skewness & 0.5 & 5.4 & 1.9 & 1.2 & -0.2 \\
\hline Kurtosis & -0.9 & 44.0 & 8.1 & 3.7 & -0.6 \\
\hline
\end{tabular}


Table 3. Annual condensed water balance of Lake Gardno during 2012-2014

\begin{tabular}{lcclcc}
\hline & INCOME & & & \multicolumn{2}{l}{ EXPENDITURE } \\
\hline Elements of income & {$\left[\mathrm{m}^{3}\right]$} & {$[\%]$} & Elements of expenditure & {$\left[\mathrm{m}^{3}\right]$} & 14015 \\
\hline Precipitation $(\mathrm{P})$ & 14978 & 87 & Evaporation $(\mathrm{E})$ & 100 \\
\hline Fog $(\mathrm{F})$ & 2258 & 13 & & 14015 & 100 \\
\hline Together & 17236 & 100 & Together & 3221 \\
\hline & & & $\begin{array}{l}\text { Retention of lake (possible } \\
\text { underground exchange) }\end{array}$ \\
\hline
\end{tabular}

lake surfaces annually. Taking into account very low variations of water levels in the lake and still fairly weak recognition of underground water inflows and outflows from/to the lake, it can be assumed that the average annual amount of waters in the lake retention $\left(3211 \mathrm{~m}^{3}\right)$ may constitute a measure of underground water exchange.

\section{Thermal regime of Lake Gardno}

The thermal regime and ice cover of Lake Gardno are affected by seasonal variability of air temperatures. The short-term dynamics of air temperatures affects the lake water temperatures, especially within its sub-surface areas $(r=0.93)$. The lake ice cover during 2012-2014 lasted for 38 days only and played a minor role in shaping the hydro-chemical properties of the lake. The longest period of ice cover (28 days) occurred from 27 January to 23 February 2012, with a maximum thickness of $26 \mathrm{~cm}$ (Fig. 4).

Water temperatures close to the lake surfaces were characterised by the highest dynamics. At a depth of $0.3 \mathrm{~m}$ the average annual water temperature was the highest $\left(11.1^{\circ} \mathrm{C}\right)$ and the water thermal activity reached a range of variability from $0.1^{\circ} \mathrm{C}(6-12$ February 2012) up to $24.0^{\circ} \mathrm{C}$ ( 29 July 2014 ). The higher the depth, the lower the decreased range of variability and water temperature extremes. At a depth of $6 \mathrm{~m}$ the average annual water temperature was equal to $7.1^{\circ} \mathrm{C}$, with the range of variability from $3.1^{\circ} \mathrm{C}$ (4 January 2014) up to $11.9^{\circ} \mathrm{C}$ (7-8 October 2012). Measurements on the thermal properties of non-consolidated bottom deposits at a depth of $7 \mathrm{~m}$ showed a relatively low level of the temperature dynamics ranging from 3.9 up to $7.4^{\circ} \mathrm{C}$ and more balanced course of temperatures of non-consolidated bottom deposits compared to temperatures of waters in the lake during the year (Table 4, Fig. 5).

Lake Gardno at the examined profile is a dimictic lake within which in the period of 2012-2014 its autumnal water overturn lasted for 44 days from midOctober to mid-December. Then its spring homoth- ermy lasted very briefly, for 4 days on average and occurred in March (2012 and 2014) and April (2013). Summer anothermy is the longest season of the thermal regime of Lake Gardno; on average it occurred for 214 days, mainly from mid-March to end-October. The range of epilimnion during summer stratification went down to a depth of $2 \mathrm{~m}$ below which thermocline occurred, which reached the lake bottom. At the time of anothermy there was no layer of hypolimnion. Then, winter thermal stratification occurred for 103 days on average - from December to mid-March. During katothermy a range of epilimnion occurred mainly down to a depth of $1 \mathrm{~m}$; there was thermocline at a depth of 1-2 $\mathrm{m}$ and below $2 \mathrm{~m}$ a layer of hypolimnion could be found. In contrast to summer stratification, the functioning of winter stratification and range of individual thermal layers were characterised by wider short-term variability (Fig. 5).

\section{Physicochemical properties of waters in Lake Gardno}

In hydrochemical terms waters in Lake Gardno are plain, double-component, bicarbonate-calcium waters. The level of concentration of oxygen in the lake provides evidence on their good quality; the highest oxygenation occurred within sub-surface layers (5.58 $\mathrm{mg} \mathrm{dm}^{-3}$ ) and the lowest concentration of $\mathrm{O}_{2}$, within demersal layers $\left(4.01 \mathrm{mg} \mathrm{dm}^{-3}\right)$. The $\mathrm{pH}$ of water is neutral (7.73) and conductance is equal to $45.7 \mathrm{mS}$ $\mathrm{m}^{-1}$ (Table 5). In terms of physicochemical parameters (Table 5), including the level of concentration of total phosphorus $\left(<0.01 \mathrm{mg} \mathrm{dm}^{-3}\right)$, waters in Lake Gardno are characterised by very good ecological conditions.

The seasonal variability of physiochemical properties of surface waters showed increased mineralisation during summer and autumn months; the lowest in winter months. Oxygenation of these waters was the highest in winter-spring months and the worst aerobic conditions in summer (Table 6).

The analysis of aerobic conditions showed improved aerobic conditions during winter thermal strati- 


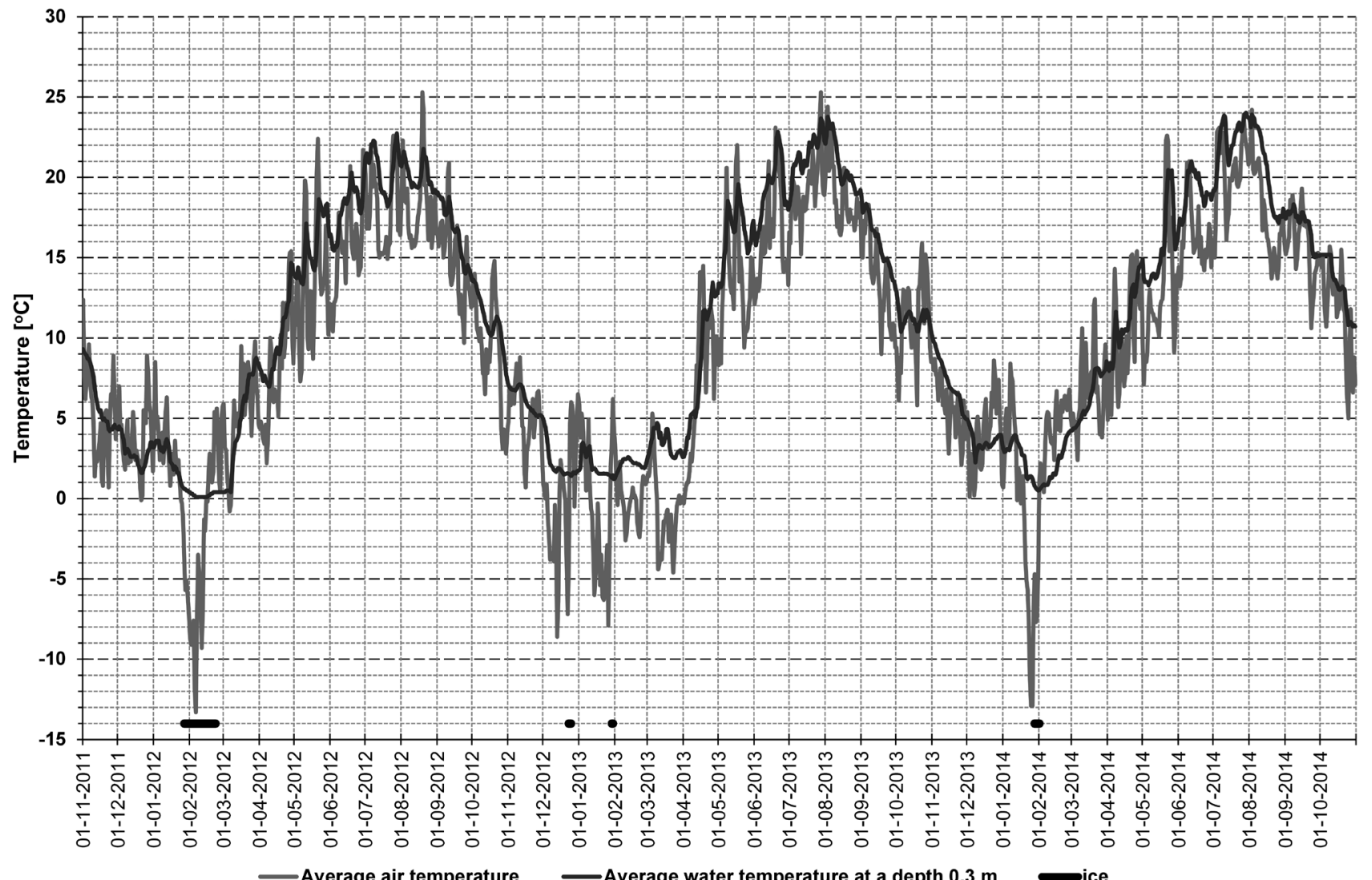

Fig. 4. Air and water temperatures at a depth of $0.3 \mathrm{~m}$ and ice cover in Lake Gardno in the analysed hydrological years (2012-2014)

Table 4. Temperature of water at depths: 0.3 (surface), 1, 2, 3, 4, 5, and $6 \mathrm{~m}$ and temperature of non-consolidated bottom deposits in Lake Gardno during the analysed hydrological years (2012-2014)

\begin{tabular}{lccccccccc}
\hline \multirow{2}{*}{ Temperature $\left[{ }^{\circ} \mathrm{C}\right]$} & \multicolumn{9}{c}{ Depth $[\mathrm{m}]$} \\
\cline { 2 - 11 } & 0.3 & 1.0 & 2.0 & 3.0 & 4.0 & 5.0 & 6.0 & Bottom \\
\hline Average & 11.1 & 11.1 & 10.6 & 9.5 & 8.3 & 7.7 & 7.1 & 7.4 \\
\hline Maximum & 24.0 & 23.5 & 22.3 & 19.6 & 16.0 & 14.4 & 11.9 & 10.8 \\
\hline Minimum & 0.1 & 0.4 & 2.2 & 2.3 & 2.5 & 2.9 & 3.1 & 3.9 \\
\hline Dispersion & 23.9 & 23.1 & 20.1 & 17.3 & 13.5 & 11.5 & 8.8 & 6.9 \\
\hline
\end{tabular}

Table 5. Physicochemical properties of Lake Gardno waters (2012-2014)

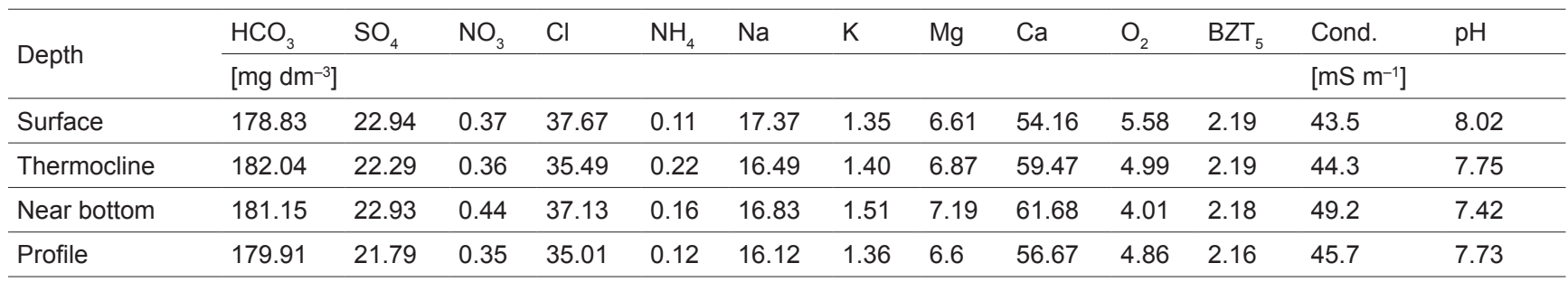

fication compared to summer stagnation. When under water mixing their thermal and aerobic conditions were similar within the entire depth profile (Fig. 6). The complete scope of thermal layers (epilimnion, thermocline and hypolimnion) occurred during katothermy only. When under anothermy no hypolimnion was found.

The susceptibility of the lake to degradation is connected with the assessment of delays or accelera- 


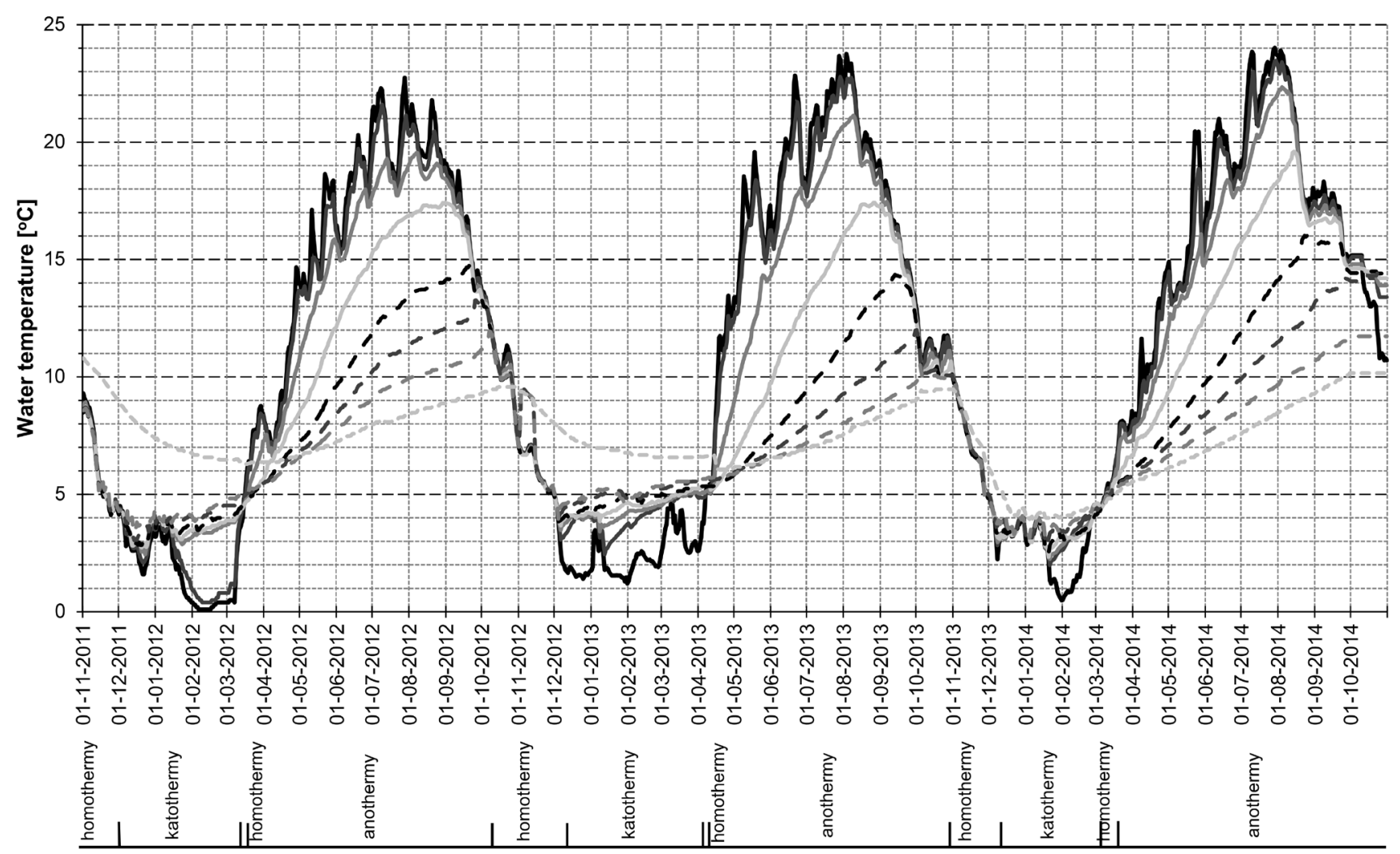

Depth

$2.0 \mathrm{~m}$

$-3.0 \mathrm{~m}--4.0 \mathrm{~m}$

$-5.0 \mathrm{~m}--6.0 \mathrm{~m}$

bottom

Fig. 5. Thermal stratification and temperatures of waters at depths: $0.3,1,2,3,4,5,6 \mathrm{~m}$ and thermal activity of bottom deposits in Lake Gardno during the analysed hydrological years (2012-2014)

Table 6 Monthly characteristics of physiochemical properties of surface waters in Lake Gardno (2012-2014) at a depth of $0.3 \mathrm{~m}$

\begin{tabular}{|c|c|c|c|c|c|c|c|c|c|c|c|c|}
\hline \multirow{2}{*}{ Month } & $\mathrm{SO}_{4}$ & $\mathrm{NO}_{3}$ & $\mathrm{Cl}$ & $\mathrm{NH}_{4}$ & $\mathrm{Na}$ & $\mathrm{K}$ & $\mathrm{Mg}$ & $\mathrm{Ca}$ & $\mathrm{O}_{2}$ & $\mathrm{BZT}_{5}$ & Cond. & $\mathrm{pH}$ \\
\hline & & \multicolumn{8}{|c|}{$\left[\mathrm{mg} \mathrm{dm}^{-3}\right]$} & \multicolumn{3}{|c|}{$\left[\mathrm{mS} \mathrm{m}^{-1}\right]$} \\
\hline$X I$ & 22.38 & 1.85 & 0.16 & 37.17 & 17.36 & 1.56 & 6.73 & 62.73 & 5.4 & 1.4 & 41.1 & 7.59 \\
\hline XII & 9.45 & 0.98 & 0.09 & 15.77 & 17.69 & 0.79 & 2.99 & 26.65 & 7.3 & 1.2 & 19.8 & 7.64 \\
\hline I & 21.68 & 1.34 & 0.30 & 38.46 & 17.04 & 1.52 & 6.52 & 55.11 & 3.9 & 0.6 & 41.0 & 7.58 \\
\hline II & 10.34 & 0.66 & 0.17 & 19.79 & 9.54 & 1.06 & 3.33 & 31.66 & 6.2 & 4.4 & 21.0 & 7.23 \\
\hline III & 14.07 & 3.30 & 0.21 & 27.22 & 12.78 & 1.45 & 4.39 & 37.27 & 6.9 & 2.6 & 28.6 & 7.46 \\
\hline IV & 22.93 & 0.49 & 0.18 & 40.60 & 18.20 & 1.50 & 6.42 & 64.53 & 6.4 & 2.8 & 39.6 & 8.09 \\
\hline V & 22.63 & 0.55 & 0.13 & 40.57 & 17.83 & 1.46 & 6.28 & 58.52 & 4.6 & 3.5 & 39.5 & 7.97 \\
\hline VI & 22.55 & 0.44 & 0.13 & 40.70 & 18.48 & 1.31 & 6.42 & 58.92 & 3.7 & 0.2 & 40.4 & 8.23 \\
\hline VII & 22.09 & 0.48 & 0.25 & 39.76 & 18.85 & 1.24 & 6.54 & 49.70 & 4.1 & 0.6 & 40.0 & 8.18 \\
\hline VIII & 23.04 & 0.59 & 0.30 & 41.63 & 18.92 & 1.32 & 6.68 & 63.33 & 4.3 & 1.2 & 41.1 & 8.00 \\
\hline IX & 22.83 & 0.41 & 0.10 & 40.19 & 18.24 & 1.35 & 6.96 & 49.50 & 3.6 & 0.2 & 41.9 & 8.70 \\
\hline$x$ & 22.05 & 0.14 & 0.25 & 39.55 & 18.32 & 1.63 & 7.05 & 49.90 & 6.8 & 0.6 & 42.4 & 7.90 \\
\hline
\end{tabular}

tion of water circulation in the catchment area and threat of eutrophication (Bajkiewicz-Grabowska 1987). Delays of water circulation are very favourable for the protection of its resources. The scope of impact of the catchment onto the lake was assessed on the basis of features characterising the whole lake catchment areas and direct catchment. Moreover, the natural resistance of the lake against degradation (as 
resulted from its morphometric parameters and water stratification) was determined (Dolański et al. 1995). Lake Gardno catchment was qualified in the $3^{\text {rd }}$ category with medium capabilities to accelerate supplies of water and biogenic matter to the lake. Its quite considerable susceptibility to degradation may also be indicated by its exposure index which is 0.96 and significantly lower than the average value for Poland, which is 30 (Choiński 1995). The low exposure index
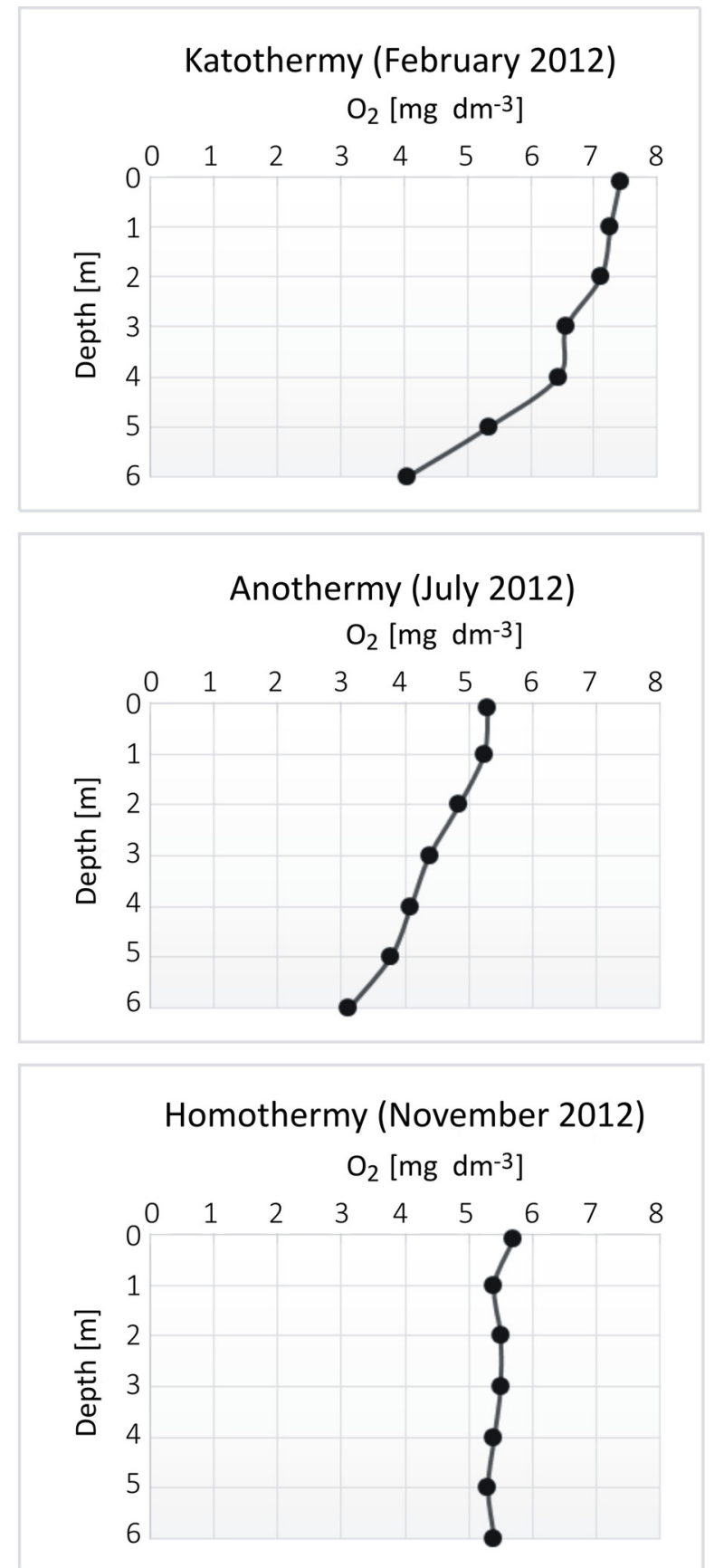

of Lake Gardno indicates its limited water circulation and resulting increased susceptibility to degradation. Lake Gardno is qualified in the $3^{\text {rd }}$ category of lakes which are poorly resistant to degradation. However, its quite low assessment of resistance is caused above all by a high value of the Schindler 40 index, which is the quotient of a total lake catchment area and its volume.

The physico-geographical structure of Lake Gardno catchment as well as its morphometry and hy-
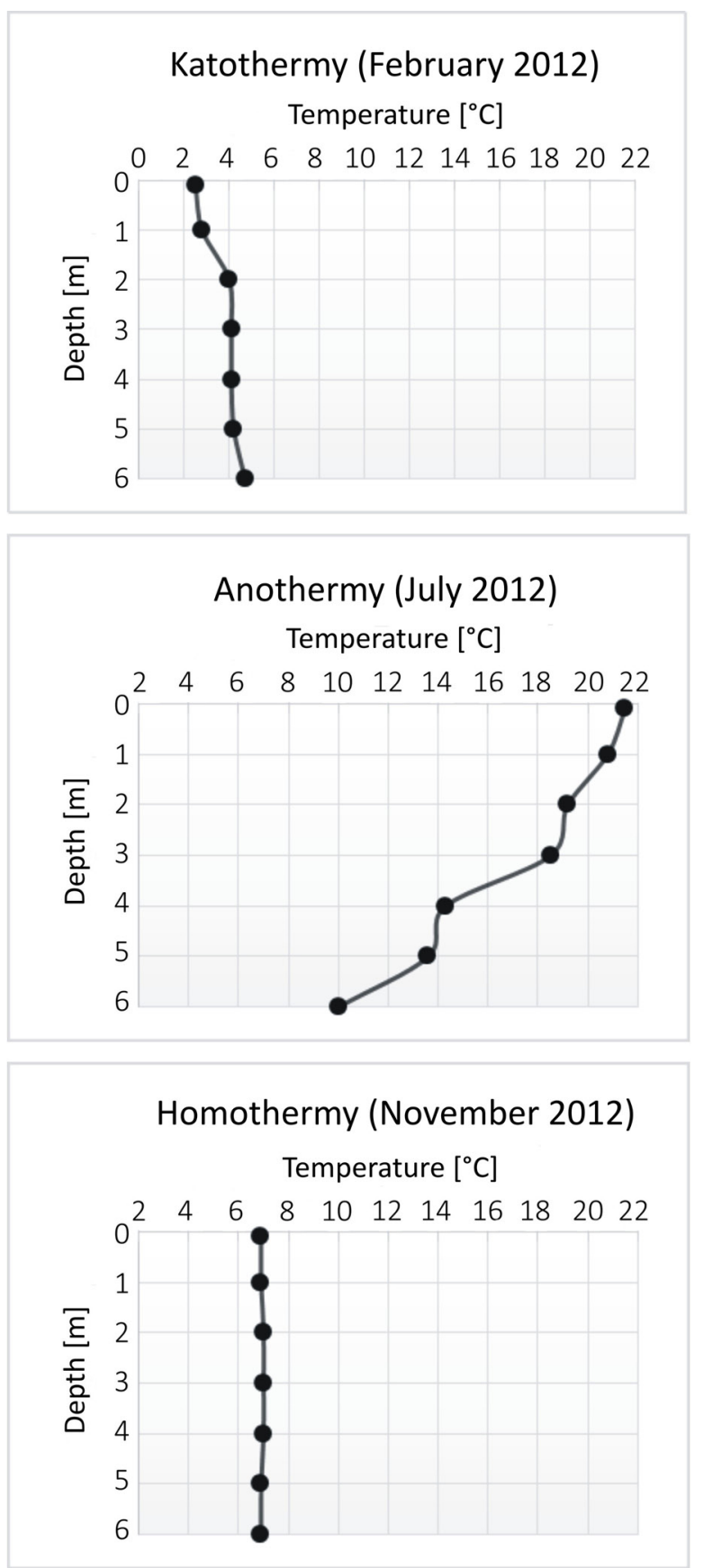

Fig. 6. Thermal and aerobic stratification of Lake Gardno - example from 2012 
drological system determine the level of its eutrophication (Bajkiewicz-Grabowska 2004). Due to a risk of eutrophication Lake Gardno can be treated as a lake geo-eco-system with its relatively favourable catchment conditions (its catchment is not very active in providing supplies to the reservoir) but the lake itself is susceptible to external impacts. Eutrophication of waters in this group has progressed moderately; however, any interference with catchment conditions can lead quite quickly to an increase in its level.

The analysis of the lake basin permanence index (BPI) (Kerekes 1977) allowed the approximate period of time during which Lake Gardno will disappear to be determined at 40 years (Samołyk 2013). The BPI which provides information on susceptibility of a given lake to degradation is defined as the ratio of its volume to its coastal length. This prompt rate of the lake disappearance especially refers to shallow water bodies in its east-western sector which have currently been in the process of rapid shallowing and overgrowing with vegetation. The lake disappearance in the forthcoming half-century does not refer to central parts of the lake and its northern bay, which are the deepest areas and vegetation development is not very intense there.

\section{Conclusions}

Lake Gardno representing a relatively small (with its area $<50 \mathrm{ha}$ ) and shallow (with its average depth $<3 \mathrm{~m}$ ) non-run-off lake located within morainic high lands of the Southern Baltic coastline is characterised with the following regularities in the range of its hydrological and physiochemical properties:

$\Rightarrow$ This is a holomictic lake, dimictic within its northern bay and polimictic within other water areas. Summer stagnation lasted the longest in the deepest lake region (for 214 days on average). Winter stagnation lasted much shorter (for 103 days on average). Spring water overturn which lasted just 4 days on average is the shortest period of the thermal regime of the lake. Autumn water overturn was longer and lasted for 44 days on average.

$\Rightarrow$ Weak dependencies of water levels in the lake in relation to weather conditions (e.g. precipitation, air temperatures) were found. Water levels in the lake are characterised by minor fluctuations $(<10$ $\mathrm{cm}$ ) which can indicate their active and stable underground exchange.

$\Rightarrow$ The lake water balance has a very low level of annual variability. Water retention resulting from ver- tical exchange due to almost constant water levels in the lake may be a measure of underground exchange. The average annual value of retention was $3221 \mathrm{~m}^{3}$, the lowest was in $2012\left(2357 \mathrm{~m}^{3}\right)$ and the highest in $2013\left(4579 \mathrm{~m}^{3}\right)$. Its water balance is primarily determined by stable underground water supplies and drainage while direct atmospheric supplies have little importance.

$\Rightarrow$ In terms of its physiochemical parameters and eutrophication index, Lake Gardno with its waters is characterised by a very good ecological status.

Lake Gardno is characterised by adverse morphometric and catchment conditions in reference to its susceptibility and resistance to degradation. Lake Gardno was qualified in the $3^{\text {rd }}$ category with medium capabilities of accelerated supplies of water and biogenic matter to the lake and little resistance to degradation.

\section{Acknowledgements}

The study was co-financed as part of project No. N N304 NCN 274340 on the Current condition and functioning of the natural environment in selected areas of the West Pomerania in view of the climate change and human impact.

\section{References}

Bajkiewicz-Grabowska E., 1982, Wymiana wody w akwenach jeziornych na przykładzie jeziora Wigry (The water exchange in the Wigry Lake basins), Prz. Geof. 27(34): 229-240 (in Polish, English summary).

Bajkiewicz-Grabowska E., 1987, Ocena naturalnej podatności jezior na degradację i rola zlewni w tym procesie (Natural degradation ability of lakes and the role of drainage area in the process), Wiad. Ekol. 33(3): 279-289 (in Polish, English summary).

Bajkiewicz-Grabowska E., 2004, Podatność jezior na eutrofizację (Susceptibility of lakes to eutrophication), [in:] Zdanowski B., Hutorowicz A, Białokoz W. (eds.), Ekosystemy wodne Parku Narodowego „Bory Tucholskie” (Water ecosystems of the "Bory Tucholskie" National Park), Wydaw. IRS, Olsztyn: 17-32 (in Polish).

Bajkiewicz-Grabowska E., 2009, Obieg wody w jeziorze Wigry (Circulation of water in Wigry Lake), [in:] Rutkowski J., Krzysztofiak L. (eds.), Jezioro Wigry. Historia jeziora w świetle badań geologicznych i paleoekologicznych (Wigry Lake. History of the lake in the light of geological and paleoecological studies), Stow. "Człowiek i Przyroda”, Suwałki: 54-67 (in Polish, English summary).

Choiński A., 1995, Zarys limnologii fizycznej Polski (An outline of physical limnology of Poland), Wydaw. Nauk. UAM, Poznań, pp. 298 (in Polish). 
Choiński A., Graf R., Kaflińska J., Jakubowski M., Wrzesiński D., Zawadzki P., 1986, Wody powierzchniowe i warunki hydrogeologiczne Wolińskiego Parku Narodowego i jego otoczenia (Surface waters and hydrogeological conditions of the Wolin National Park and its surroundings), [in:] Kostrzewski A. (ed.), Woliński Park Narodowy. Monografia geograficzna (Wolin National Park. Geographical monograph), SKNG UAM, Poznań: 32-41 (in Polish).

Choiński A., Kowalski G., Świrko A., Zimmer A., 1978, Stosunki wodne wyspy Wolin (Water relations of Wolin Island), [in:] Kostrzewski A. (ed.), Studia z geografii fizycznej i ekonomicznej wyspy Wolin (Studies of physical and economic geography of Wolin Island), SKNG UAM, Poznań: 33-56 (in Polish).

Dolański A., Godowac D., Rolle Sz., Wrzesiński D., 1995, Ocena podatności jezior Wolińskiego Parku Narodowego na degradację i znaczenie warunków przyrodniczych zlewni w tym procesie (Evaluation of the susceptibility of the Wolin National Park lakes to degradation and significance of the natural conditions of their catchments in this process), Klify: 33-40 (in Polish).

Kerekes J., 1977, The index of lake basin permanence, Int. Revue ges. Hydrobiol. Hydrogr. 62(2): 291-293.

Kolander R., Kostrzewski A., Tylkowski J., 2008, Seasonal variations in the chemical composition of water circulation in the Lake Gardno catchment on Wolin Island, Queast. Geogr. 27(2): 21-27.

Kolander R., Tylkowski J., 2008, Hydrochemical seasons in the Lake Gardno catchment on Wolin Island (north-western Poland), Limnol. Rev. 8(1-2): 27-34.

Kostrzewski A., 2003, Obieg wody i jego wpływ na powstanie i funkcjonowanie struktur krajobrazowych strefy młodoglacjalnej (Polska Północno-Zachodnia, Pomorze Zachodnie) (Water circulation and its impact on the creation and functioning of landscape structures of the young glacial zone: North-Western Poland, Western Pomerania), [in:] Kostrzewski A., Szpikowski J. (eds.), Funkcjonowanie geoekosystemów zlewni rzecznych. Obieg wody, uwarunkowania i skutki w środowisku przyrodniczym (Operation of river catchment geoecosystems. Water circulation, conditions and effects on the natural environment), Bogucki Wydaw. Nauk., Poznań: 17-20 (in Polish).

Kostrzewski A.,Samołyk M., Tylkowski J.,2011,Indywidualność przyrodnicza funkcjonowania geoekosystemu zlewni Jeziora Gardno: Wyspa Wolin (Natural individuality of the operation of Lake Gardno catchment geoecosystem: Wolin Island), [in:] Kostrzewski A., Samołyk M. (eds.), Zintegrowany monitoring środowiska przyrodniczego: funkcjonowanie geoekosystemów w warunkach zmian klimatu i różnokierunkowej atntropopresji (The integrated monitoring of the natural environment: the operation of geoecosystems in the conditions of climate changes and the multi-directional human impact), Biblioteka Monitoringu Srodowiska 28: 121-136 (in Polish).

Kubiak J., 2001, Hydrochemistry of Wolin Island Lakes, Folia Univ. Agric. Stettin. Piscaria 218(28): 63-76.
Kubiak J., 2003, Eutrophication rate and trophic state of Western Pomeranian coastal Lakes, Acta Sci. Pol. Piscaria 2(1): 141-158.

Matkowska Z., 1973, Charakterystyka warunków hydrogeologicznych wysoczyzny wyspy Wolin (Characteristics of hydrogeological conditions of the upland plain of Wolin Island), Kwart. Geol.17(3): 592-593 (in Polish).

Mikulski Z., 1970, Kształtowanie się bilansu wodnego jezior w Polsce (Shaping of the water balance of lakes in Poland), Prz. Geogr. 42(3): 433-447 (in Polish, English summary).

Nowacki F., 1994, Bilans wodny i zasoby wodne wyspy Wolin i Wolińskiego Parku Narodowego (Water balance and water resources of Wolin Island and the Wolin National Park), Klify 1: 119-135 (in Polish).

Pluciński J., 2009, Kopanie złota na Wolinie (Gold mines at Wolin Island), iswinoujscie.pl - Wydarzenia. Retrieved from http://www.iswinoujscie.pl/artykuly/9321/ (in Polish).

Poleszczuk G., Grzegorczyk K., Bucior A., Jóźwik I., 2006,„Cztery pory roku" jakości wód powierzchniowych jezior Warnowo (Warnowo Zachodnie) i Rabiąż (Warnowo Wschodnie) w Wolińskim Parku Narodowym ("Four seasons" of the quality of surface waters in the Warnowo Lake (Warnowo Zachodnie) and Rabiąż (Warnowo Wschodnie) in the Wolin National Park), Zesz. Nauk. USzczec. Acta Biologica 449(13): 147-161 (in Polish, English summary).

Rutkowski J., Rudowski S., Pietsch K., Król K., Krzysztofiak L., 2002, Sediments of Lake Wigry (NE Poland) in the light of high-resolution seismic (seismoacoustic) survey, Limnol. Rev. 2: 363-371.

Samołyk M., 2013, Charakterystyka nadmorskiej zlewni rzeczno-jeziornej Lewińskiej Strugi (Wyspa Wolin) (Characteristics of the coastal and river-lake Lewińska Struga catchment: Wolin Island), [in:] Florek W. (ed.), Geologia i geomorfologia pobrzeża i południowego Bałtyku. Tom 10 (Geology and geomorphology of coastland and southern Baltic Sea. Vol. 10), Wydaw. AP w Słupsku, 10: 167-178 (in Polish, English summary).

Samołyk M., Tylkowski J., 2012, Charakterystyka właściwości hydrologicznych brzegu klifowego wyspy Wolin w latach 2009-2010 (Characteristics of hydrological properties of cliff coasts of the Wolin Island within 2009-2010), [in:] Kostrzewski A., Szpikowski J. (eds), Zintegrowany monitoring środowiska przyrodniczego: funkcjonowanie geoekosystemów w różnych strefach krajobrazowych Polski (The integrated monitoring of the natural environment: the functioning of geoecosystems in the various Polish landscape zones), Biblioteka Monitoringu Środowiska 29: 199-208 (in Polish, English summary).

Tylkowski J., 2013, Temporal and spatial variability of air temperature and precipitation at the Polish coastal zone of the Southern Baltic Sea, Baltica 26(1) 79-90.

Walczak M., 2013, Oznaczanie zawartości mikroskładników w osadach dennych Jeziora Gardno: Woliński Park Narodowy (Determination of micro-components in bottom sediments of Lake Gardno: Wolin National Park) [Thesis], UAM, Wydział Biologii, Poznań, pp. 71 (in Polish). 